\title{
Radiocarbon
}

1987

\section{CLIMATIC IMPLICATIONS OF CHENIER DATES IN NORTHERN AUSTRALIA}

\author{
BRIAN G LEES \\ Department of Geography, Australian National University \\ Canberra, ACT, Australia
}

\begin{abstract}
ANNEMARIE CLEMENTS
School of Biological Sciences, University of Sydney, NSW, 2006, Australia

ABSTRACT. The characterization of late Holocene climates in northern Australia has, in the past, been based on local investigations. This examination of the chenier record of northern Australia indicates that there has been a statistically significant regional change in conditions between 1600-2800 years BP, possibly a period of relative aridity. Support for this conclusion may be found in the vegetation record from the Atherton Tableland where numerical comparisons of dryland fossil and modern pollen spectra suggest that rainfall may have been up to $50 \%$ higher during the period 7000 to $3000 \mathrm{BP}$.
\end{abstract}

Chenier plains are a form of beach-ridge plain characterized by ridges of shell or sand with broad inter-ridge areas of mud flat. They are particularly sensitive indicators of environmental change. Minor changes in localized hydrologic and sedimentation patterns are responsible for alternate chenier ridge and inter-chenier mud-flat progradation. The classic form of this type of beach-ridge plain is on the marginal deltaic plain of the Mississippi (Russell, 1953; Gould \& McFarlane, 1959; Byrne, Leroy \& Riley, 1959). These cheniers are formed during periodic shifts in the river mouth location, but delta switching is only one of several processes which can lead to the formation of chenier plains. Episodic erosion was initially seen as one of the necessary criteria for chenier genesis. The other criteria originally maintained were an effective alongshore current, a variable supply of sediment, and a stable or recessive sea level. Russell and Howe (1935) maintained that periodic variation in fluvial sediment supply is critical for the formation of cheniers which are the result of beach reworking along a retreating coastline. Gould and McFarlane (1959) argued that the Louisiana ridges were accretionary features along a stable coastline thus eliminating the erosional aspect of genesis. Subsequent investigations of some of the Louisiana cheniers by Coleman (1966) indicated that both conditions may have operated along different parts of the same ridge at the same time. Given a fairly constant marine hydraulic environment and a sedimentary environment in which cheniers could develop, fluctuations in alongshore sediment supply can result in the building of cheniers. Equally, given a fairly constant supply of sediment, an increase in the energy intensity of the marine hydraulic environment may lead to a change from mud-flat deposition to chenier development. The important feature of the environment in 
which chenier plains develop is a periodic variation in the balance between fluvial and marine forces.

Broad Holocene coastal plains with wide intertidal and supratidal flats interspersed with cheniers are common in northern Australia. These are mostly recent features. Rhodes (1980) and Rhodes et al (1980) identified periods of chenier development in the Gulf of Carpentaria between 4500$2900 \mathrm{yr}$ BP, between $2000-1700 \mathrm{yr}$ BP and between $1300 \mathrm{yr}$ BP and the present. He postulated there was a lack of fine terrigenous material available for mud-flat progradation during these periods and suggested that these were periods of low fluvial input separated by periods of increased fluvial input when mud-flat progradation took place. An alternate hypothesis is proposed by Chappell and Grindrod (1984) who argue that increasing muddy sedimentation reduces shell production in the lower intertidal and subtidal source area of the cheniers in northeastern Princess Charlotte Bay, thus reducing the raw material supply for chenier building. Both explanations associate high mud input with the deposition of tidal flats and low mud input with chenier ridge production. This fluctuation in mud input to the system may reflect the fluvial response to changes in rainfall. It seems unlikely, given the few ridges on most chenier plains in comparison to the number of major storms most chenier plains must have experienced, that chenier building is the necessary result of high energy events such as the passage of a tropical revolving storm. Certainly, not all storms build cheniers (Chappell \& Grindrod, 1984; Lourensz, 1981). The building of sandy cheniers may, nevertheless, be the result of a series of closely spaced storms during periods of reduced fluvial input. Unlike the eastern Australian coast, the northern Australian coast is compartmentalized into a series of marginal seas. The effect of storm-generated waves is restricted by this compartmentalization and even a general increase in the frequency of storms would not result in near-synchronous chenier building across northern Australia unless several succeeding storms followed similar tracks through each of the compartments. Available records (Lourensz, 1981)

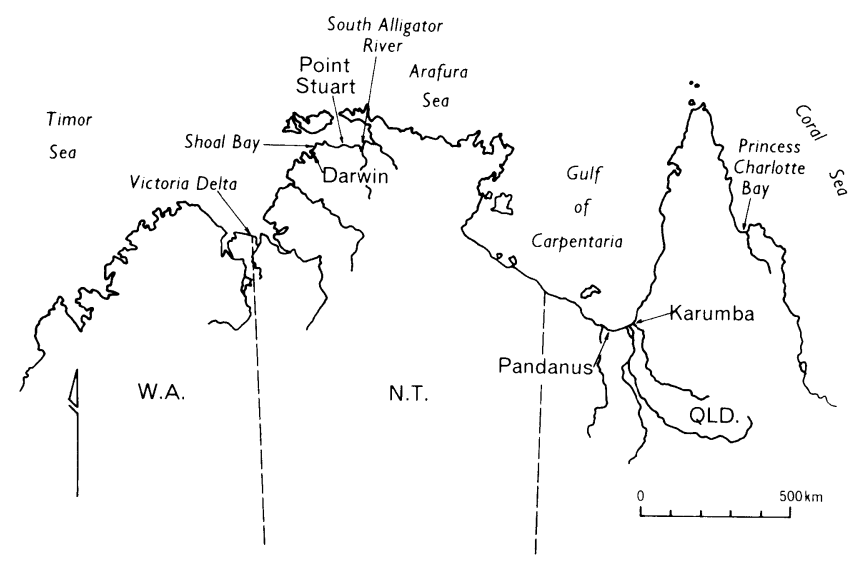

Fig 1. Location diagram of Northern Australia 
indicate that this is improbable. The building of cheniers by a sequence of storms can be considered a "local" variable occurring randomly.

In Rhodes' (1980) investigation of the coastline of the Gulf of Carpentaria he found that there were, at that time, insufficient data on upper Holocene climatic change for regional correlation. Other investigations of coastal depositional features in northern Australia that involve the dating of chenier plains include the delta of the Mary River at Point Stuart (Clarke, Wasson \& Williams, 1979), Shoal Bay (Hickey, 1981), the delta of the Victoria River (Lees, 1985), the delta of the Normanby River in Princess Charlotte Bay (Chappell \& Grindrod, 1984), and the delta of the South Alligator River (Woodroffe et al, 1985) (Fig 1). These studies range across northern Australia and provide a data base for testing regional, rather than local, environmental change.

Calibrated ${ }^{14} \mathrm{C}$ ages (Klein et al, 1982) of shell from 7 dated crosssections of northern Australian chenier plains from 6 studies are shown in Figure 2. None of the ages were obtained using shells of Ostreidae. Two of the transects from the Gulf of Carpentaria have been used: the Pandanus Yard transect and the Karumba transect described by Rhodes (1980). The other transects are from different coastal compartments. Patterns of time of chenier formation are being tested using a chi-square test statistic, $\chi^{2}$, and "Robinson" clump test statistic, R (named after John Robinson). The null hypothesis is that chenier ridges are formed by random, local events. Shells incorporated into chenier ridges lived at some time before they were deposited. However, it is assumed that the calibrated ${ }^{14} \mathrm{C}$ ages of the shells are reasonable estimates of the time of formation of the chenier ridges.

Six data sets are used in the analyses. The data set from Point Stuart is

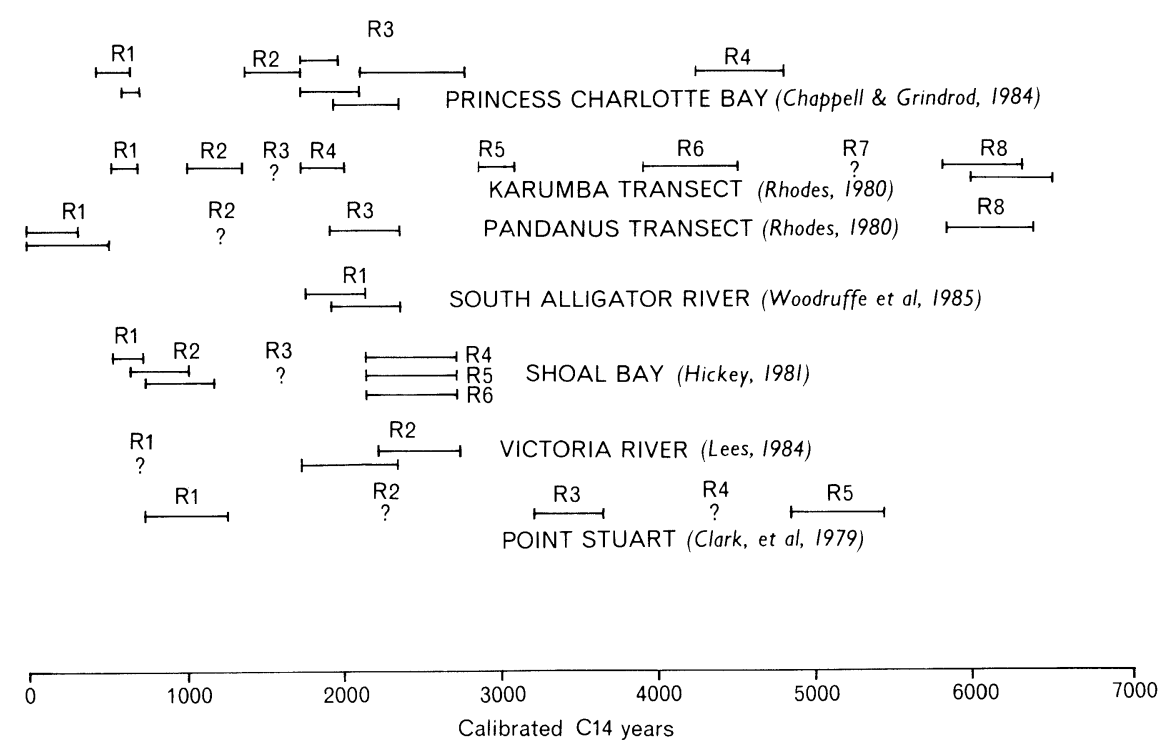

Fig 2. Environmentally corrected and calibrated ages of cheniers in Northern Australia 
excluded as only alternate chenier ridges were dated. The data set does not consist of discrete points in time due to the error bands associated with ${ }^{14} \mathrm{C}$ dating (Fig 2). The continuous variable, time, is divided into intervals. The time interval (window width) is chosen to maximize the observable differences and, hence, minimize the observed significant level of the chi-square statistic (Table 1). Plotting the data with a time interval of 200 years, there appear to be two clumps, at $1600-2800$ years BP and at $400-800$ years $\mathrm{BP}$, respectively (Fig 3).

In order to apply a standard chi-square test, the sample size, the number of chenier plains 'observed' (Fig 3), should be sufficiently large, say 4 or 5 times the number of cells (the number of time intervals). Sometimes the rule of thumb is that the expected value, e, should be at least five, but this is unnecessarily conservative (Lindgren, 1976). In this case, e, the sum of occurrences of cheniers over the time interval (59) divided by the number of the time intervals (33) (Fig 3) is equal to 1.78; hence the calculated chisquare for this particular set of observations cannot be validly compared with the standard chi-square distribution. Further, the optimization of the time interval using the chi-square statistic also invalidates use of the standard chi-square statistic.

The distribution of chi-square and "Robinson" clump test statistics are generated by using randomization procedures so that measures of statistical significance can be applied. The procedure consists of randomization in each of the six observed data sets. For example, in the Princess Charlotte Bay data, there are four occurrence groups (Table 1), which are $400-800$ years, $1200-2800$ years, $4200-5000$ years, and $5800-6000$ years BP. That is 2 lots of 200 years, 8 lots of 200 years, 4 lots of 200 years, and 4 lots of 200 years, respectively. The starting positions for each of the four occurrence groups are randomized with regard to time. The outcomes are bounded above by 6600 years BP, and below by 0 years BP. Randomizations outside this range that are produced are rejected and the procedure repeated until 1000 randomizations within the range have been calculated. From each full randomization the occurrence totals, $\sigma$, in 200-year time intervals across the 6 chenier plains, the chi-squared and the "Robinson" clump statistic, R, are calculated. The distribution of the statistics are based on 1000 full randomizations.

TABLE 1

The effect of increasing the time interval (window width) on the chi-squared value

\begin{tabular}{lccc}
\hline Time interval & $\begin{array}{c}\text { Degrees of } \\
\text { freedom }\end{array}$ & Chi-square & $\begin{array}{c}\text { Significance } \\
\text { level }\end{array}$ \\
\hline $100 \mathrm{yr}$ & 65 & 75.9 & $0.1-0.5$ \\
$200 \mathrm{yr}$ & 32 & 44.5 & $0.05-0.1$ \\
$400 \mathrm{yr}$ & 16 & 18.8 & $0.1-0.5$ \\
$600 \mathrm{yr}$ & 10 & 9.7 & $0.1-0.5$ \\
$800 \mathrm{yr}$ & 8 & 9.0 & $0.1-0.5$ \\
$1000 \mathrm{yr}$ & 6 & 7.7 & $0.1-0.5$ \\
$2000 \mathrm{yr}$ & 3 & 3 & $0.1-0.5$ \\
$4000 \mathrm{yr}$ & 1 & 1 & $0.5-0.9$ \\
$8000 \mathrm{yr}$ & 0 & 0 & \\
\hline
\end{tabular}




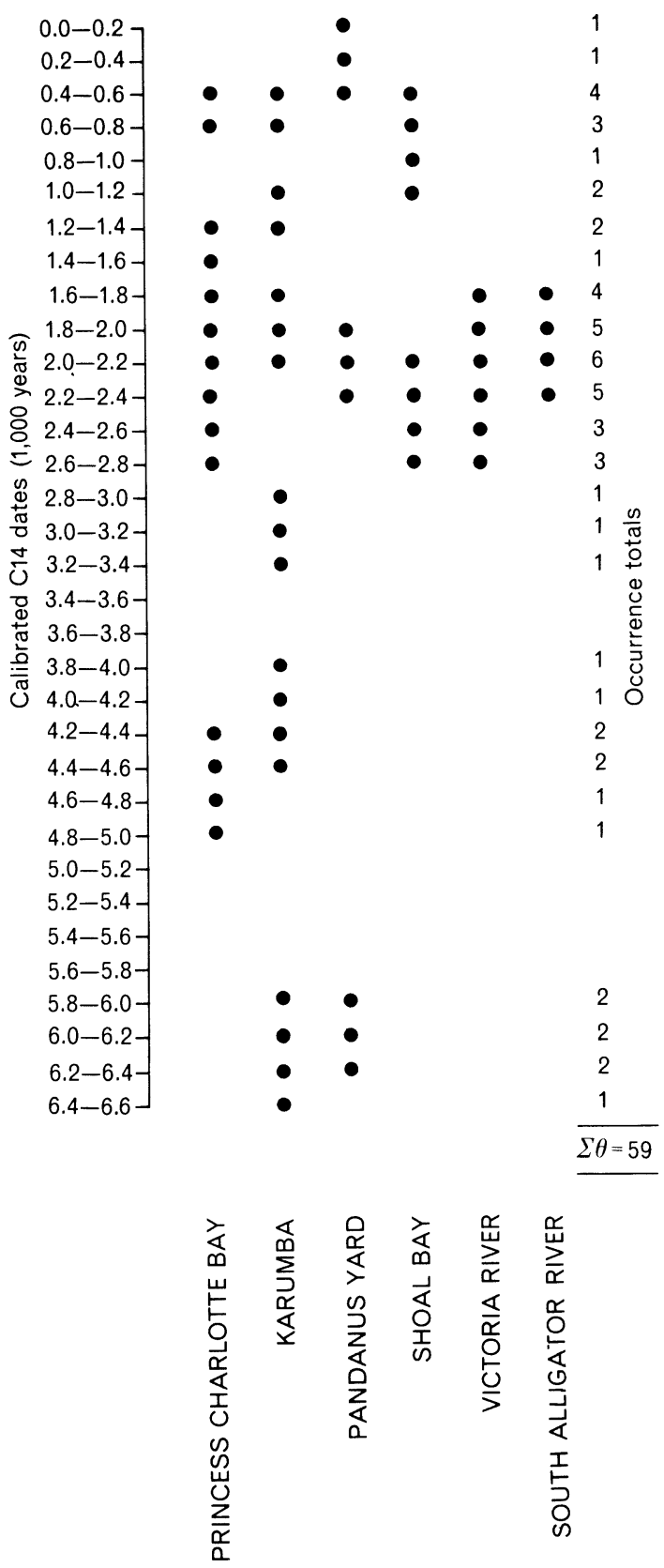

Fig 3. Occurrence pattern of cheniers in Northern Australia 
The "Robinson" clump statistic, $\mathrm{R}$, is the maxima of sums of consecutive occurrence of at least 3 cheniers out of a possible 6 cheniers in any 200-year time interval (at least half the sites have a chenier formed during the time interval). In the observed data set $\chi^{2}=44.5$ and $\mathrm{R}=26 . \mathrm{A} \chi^{2}>$ 44.5 occurs 15 times in 1000 observations. $\mathrm{R} \geq 26$ occurs 16 times in 1000 observations. The peak at $1600-2800$ years BP is statistically significant at ca $1.5 \%$.

In order to test for the second clump at $400-800$ years BP, the data contributing to the first significant clump was removed and the procedure repeated. The $R \geq 7$ occurs at random with a probability of $19 \%$ and the $\chi^{2} \geq 20.1818$ occurs by chance only $37.9 \%$ of the time. This is not statistically significant, however, the data set for this most recent event is poor. The present beach/chenier ridge on the Victoria Delta was not dated and the data set from Point Stuart was excluded.

In conclusion, non-random chenier formation occurred between $1600-2800$ years BP across northern Australia. The chenier record indicates a widespread, regional, change in climatic conditions between these dates.

Much of the work on Quaternary climatic change in Australia deals with comparatively large-scale changes in the Pleistocene; few studies incorporate the late Holocene record. This is due, in part, to the insensitivity of many of the indicators of climatic change used. As discussed above, local chenier records are ambiguous indicators of environmental change. However, at a regional level, and at the significance levels demonstrated, the published chenier record of northern Australia indicates significant environmental change in the late Holocene. The climate of northern Australia is characterized by marked wet and dry seasons. It is suggested that the period of regional chenier building is related to a reduction in the fluvial input to the coast, indicating a period of decreased wet season precipitation.

Other indications of such a change in environmental conditions at this time have been reported on a more local level. Numerical comparisons of dryland fossil and modern pollen spectra from the Atherton Tableland suggest that rainfall may have been up to $50 \%$ higher than present during the period 7000 to $3000 \mathrm{BP}$ (Kershaw, 1981). Similarly, in a statistical investigation of the depositional history of two chenier plains in North Queensland, Chappell and Thom (1986), using the Kolmogorov-Smirnov statistic, identified two periods of abnormally high rates of chenier formation. These were between 1700 and $2200 \mathrm{BP}$, and 4210 and $5090 \mathrm{BP}$. However, these results must be viewed with caution as this particular test involved the generation of an ' $n$ ' of 5 by using 3 transects through the Gulf of Carpentaria chenier plain and 2 transects through the Princess Charlotte Bay chenier plain.

In Central Australia, Wasson (1976) notes changes in conditions ca $2500 \mathrm{BP}$ on the Cobar Plain, at ca $2300 \mathrm{BP}$ in the Strzelecki Dunefield, and between ca 2200 and ca $2800 \mathrm{BP}$ in the Simpson Dunefield (Wasson, 1984). All of these represent the onset of dune-sand accumulation. Wasson (1984) argues that this was a period of lowered temperatures and precipitation coupled with an increase in the variability of the climate. 


\section{ACKNOWLEDGMENTS}

We would like to acknowledge the considerable help of John Robinson and Roger Carolin in the preparation of this paper and to thank Peter Durie for computing assistance. We are grateful for helpful comments made on the original paper by one of the referees, Bruce Thom, some of which we have incorporated. These results were first presented at a symposium on Recent sediments in Eastern Australia held at Sydney University, February 1985 .

\section{REFERENCES}

Byrne, J V, Leroy, D O and Riley, C M, 1959, The chenier plain and its stratigraphy, southwestern Louisiana: Trans Gulf Coast Assoc Geol Socs, v 9, p 237-260.

Chappell, J and Grindrod, J, 1984, Chenier plain formation in Northern Australia, in Thom, B G, ed, Coastal geomorphology in Australia: Sydney, Academic Press, p 197-229.

Chappell, J and Thom, B G, 1986, Coastal morphodynamics in North Australia: review and prospect: Australian Geog Studies, v 24, p 110-127.

Clarke, M F, Wasson, R J and Williams, M A J, 1979, Point Stuart chenier plain and Holocene sea-levels in northern Australia: Search, v 10, no. 3, p 90-92.

Coleman, J M, 1966, Recent coastal sedimentation-central Louisiana coast: Louisiana State Univ Coastal Studies, no. 17

Gould, H R and McFarlane, E, 1959, Geological history of the chenier plain, southwestern Louisiana: Trans Gulf Coast Assoc Geol Socs, v 9, p 261-270.

Hickey, S H, 1981, Preliminary investigation of stranded beach ridges, Shoal Bay, N T. A small chenier plain?: N T Geol Survey, Tech rept GS81/1.

Kershaw, A P, 1981, The vegetation record from northeastern Australia, $7 \pm 2 \mathrm{KA}$, in CLIMANZ conf, 1st, Proc: Howman's Gap, Australia.

Klein, J, Lerman, J C, Damon, P E and Ralph, E K, 1982, Calibration of radiocarbon dates: Tables based on the consensus data of the Workshop on Calibrating the Radiocarbon Time Scale: Radiocarbon, v 24, no. 2, p 103-150.

Lees, B G, 1985, Geomorphology and development of the Victoria delta, in Bardsley, K Woodroffe, C and Davies, J, eds, Coasts and tidal wetlands of the Australian monsoon region: Darwin, Northern Australian Research Unit.

Lindgren, B W, 1976, Statistical theory: New York, MacMillan Pub Co.

Lourensz, R S, 1981, Tropical cyclones in the Australian region, July 1909 to June 1980: Canberra, Australian Govt Pub Service.

Rhodes, E G, (ms) 1980, Modes of coastal progradation, Gulf of Carpentaria. PhD dissert, Australian Natl Univ, Canberra, Australia

Rhodes, E G, Polach, H A, Thom, B G and Wilson, S R, 1980, Age structure of Holocene coastal sediments: Gulf of Carpentaria, Australia, in Stuiver, M and Kra, R S, eds, Internatl ${ }^{14} \mathrm{C}$ conf, 10 th, Proc: Radiocarbon, $v 22$, no. 3, p 718-727.

Russell, R J, 1953, Coastal advance and retreat in Louisiana: Internatl Geol Cong, 19th, Algiers, SII, IV p 108-118.

Russell, R J and Howe, H V, 1935, Cheniers of southwest Louisiana: Geog Rev, v 25, p 449 461 .

Wasson, R J, 1976, Holocene aeolian landforms in the Belarabon area, SW of Cobar, NSW: Royal Soc NSW, Proc, v 109, p 91-101.

1984, Late Quaternary paleoenvironments in the desert dunefields of Australia, in Vogel, J C, ed, Late Cainozoic palacoclimates of the Southern Hemisphere: Rotterdam, Balkema, p 419-432.

Woodroffe, C I, Chappell, J, Thom, B G and Wallensky, E, 1985, Holocene morphology of the South Alligator River, N T, in Bardsley, K, Woodroffe, C and Davies, J, eds, Coasts and tidal wetlands of the Australian monsoon region: Darwin, Northern Australian Research Unit. 